\title{
Auditor Independency as Antecedents of Ethical Perception on Auditor Judgment: Study of Public Accounting Firm Auditors
}

\author{
Bima Cinintya Pratama \\ Universitas Muhammadiyah Purwokerto \\ BimaCinintyaPratama@ump.ac.id
}

\begin{abstract}
This study investigates the role of auditor independency as the antecedents of the interaction effects between ethical perception towards audit judgment taken by auditors. Total samples of seventy-two auditors in public accounting firm were provided with a set of questionnaire to see their perception of audit judgments. The sample was conducted by convenience sampling method. Analyses of data using Partial Least Square (PLS) method found that ethical perception and auditor independency significantly affect audit judgment taken by auditors. In addition, this study find that auditor independency can mediate the relationship between ethical perception and auditor judgment.
\end{abstract}

Keywords: ethical perception, auditor independency, audit judgment.

\section{INTRODUCTION}

In the era of globalization, the business world and society has become increasingly complex that demands of the development of various disciplines including accounting has arisen highly. Accounting plays an important role in economic and social aspects, because every financial decision-making must be based on accounting information. This makes the accountant as the profession that is needed in the environment of business organizations. Special skills such as business data management into computer-based information, financial and nonfinancial audits, the subject matter to tax legislation are things that can give more value to the accounting profession.

Along with Indonesia's economic growth that is expected to be better, so is the accounting profession that is needed in helping to make it happen. This condition leads to a consequence that it is still widely open for everyone to enter accounting profession as an accountant, and the accountant profession also deemed as a promising career choice.

There were many cases of companies fallen because of their business failures and also attributed because of auditors, those cases threaten the credibility of financial statements and the auditors themselves. Audit judgment is very important in generating the audit report. Audit judgment is necessary because the audits are not conducted on all of the evidence. Those evidence is used to express an opinion on the audited financial statements, so it can be said that the audit 
judgment also determining the outcome of the audit result. Mulyadi (2002) said that Audit Judgment is the policy of the auditor in determining the opinion about the results of the audit based on the formation of an idea, opinion or estimation of an object, event, status, or other types of events. Threat to the credibility of the financial statements influencing the public perception, especially for the users of audited financial statements. The audit result quality is important because high quality audit report will produce more reliable financial report as a basis for decision making.

It is interesting to note that the public accounting profession is like a double-edged sword. On one hand the auditor should pay attention to the credibility and professional ethics. The ethics of this profession must be more than moral principles (Boynton, 2003). This ethic includes the standards of conduct for a professional devoted to practical and idealistic purposes intended to direct a permanent person in the corridor of good conduct in the conduct of his profession. On the other hand, the auditor must also face pressure from the client in various decision-making. If the auditor is unable to resist the pressure of the client such as personal, emotional or financial pressure then the auditor's independency has decreased and may affect their judgment and audit quality.

Auditor must be independent in issuing their opinion and in issuing their audit report afterwards. Arens and Loebbecke (2003) define independency in auditing means holding an impartial view in the conduct of audit testing, evaluation of audit results, and the preparation of audit reports. Without independency, being auditor does worth anything. The public does not believe in the auditor's results so that the public will not seek auditing services from the auditor. In other words, the existence of the auditor is determined by his/her independency. The second common standard (SA section 220 in SPAP, 2001) states that in all matters relating to engagement, independency in the mental attitude must be maintained by the auditor. This standard requires that auditors be independent (not easily influenced), as they perform their work in the public interest. Thus they are not justified to be in favor of anyone's interest, because no matter how perfect the technical expertise they possess, they will lose their independency which is very important to maintain their freedom of opinion. The independency referred above does not mean the attitudes of a prosecutor in a court case, but more like the impartiality of a judge. The auditor recognizes the obligation to be honest not only to the management and owners of the company, but also to creditors and others who place confidence in the independent auditor's report, such as prospective owners and creditors.

Testing on audit judgment is important because in the Public Accounting Professional Standards (SPAP), auditors are required to use professional judgment in assessing matters related to the examination. The more precise audit judgment made by the auditor the more accurate the audit results. There are still 
inconsistencies in the results of research on audit judgment in Indonesia (Hartanto 2001; Zulaikha 2006). This is because the judgment made by the auditor is a subjective consideration of an auditor and is highly dependent on the individual's perception of a situation.

This study aims to investigate the influence of professional ethic perception and independency on the audit judgment. In addition, this study also tests the role of auditor independency as the antecedents of the interaction effects between ethical perception towards audit judgment taken by auditors. The expected contributions of this research are: (1) contributing to the development of theories, especially those related to auditing and behavioral accounting, (2) providing additional empirical evidence in the accounting literature, particularly on the area of professional ethic perception, independency, and audit judgment, (3) providing additional description of the dynamics that occur within the auditor environment, especially in terms of audit judgment.

\section{LITERATURE REVIEW AND HYPOTHESIS DEVELOPMENT $\mathrm{X}$ and $\mathrm{Y}$ Theory}

McGregor presents two views about humans namely the theory of $\mathrm{X}$ (negative) and the theory of $\mathrm{Y}$ (positive). Individuals with type $\mathrm{X}$ have external locus of control where they basically dislike work, avoid it and avoid responsibility, so they have to be forced or threatened with punishment for achieving goals. Y-type individuals have an internal locus of control where they like work, are able to control themselves to achieve goals, are responsible, and able to make innovative decisions (Robin and Judge 2007).

Auditors who are included in type $X$ if they are getting pressure of obedience, lack of skepticism, and their independency are not strong, they will tend to make inappropriate judgments. Those auditors cannot perform its responsibilities as an auditor, preferring to put security above all factors associated with work, so that they will tend to find a safe and even dysfunctional way of making judgments. While the auditor who is included in the type Y can be responsible for the task and remain professional in performing duties as an auditor. The auditors will not be easily affected even if he gets pressure from other parties, so they can make a better and proper judgment.

\section{Ethical Perception}

Ethics is the moral principles or values. Each person has own value preferences, though could not explicitly disclosed. Professional ethics must be more than just moral principles (Boynton, 2003). These ethics include code or standards of conduct for a professional which is devoted to practical and idealistic goals. Ideal behavior could be pursued through designing professional code of 
conducts, so the professional code of conducts should be realistic in order to be implemented.

Auditors should comply with the code of conduct that has been set. Audit must comply with the audit standards, and auditors should comply with the code of conduct which is an integral part of the auditing standards. The code of conduct is made to regulate the relationship between: (1) Auditors with clients, (2) Auditors with superiors, (3) Auditors with colleagues, and (4) Auditors with community.

\section{Auditor Independency}

In performing their duties, public accountants gaining the trust of clients and users of financial statements to prove the fairness of the financial statements prepared and presented by the client. Therefore, in providing a fairness opinion regarding the audited financial statements, a public accountant should maintain an independent mental attitude in providing professional services as stipulated in the professional standards of public accountants set by the Indonesian Institute of Accountants, both for the benefit of clients, users of financial statements, as well as the interests of the public accountants themselves.

Independency defined as the mental attitude that is free from influences, not controlled by others, and not depends on others. Independency can also be defined as honesty inside the auditors themselves in considering the facts and existence of objective consideration in deciding and expressing their opinions (Mulyadi, 2002).

If an independent auditor or a public accounting firm failed to maintain their independency, the society will think that public accountants are not independent. The suspicion may result in reduced or loss of public beliefs towards the credibility of independent auditor profession.

America Institute of Certified Public Accountant (AICPA) stated that independency is the ability to act based on the integrity and objectivity. Although the integrity and objectivity cannot be measured with certainty, but both are essential for the public accounting profession. Integrity is a moral principle that fair, honest, look and express real fact as it is.

Arens and Loebbecke (2003) defined independency in auditing means that holding on a fair or impartial view on the implementation of audit test, evaluation of test results, and the preparation of audit reports. Fairness can be formed in two perspectives, as follows:

1. Independency in fact which means that accountants can maintain fair attitudes in conducting the audit.

2. Independency in appearance which means that accountants act fair according to the perception of financial statements users. 
From explanations above, independency is an important thing that has to be possessed by auditors. An independent auditor will provide more fair judgments and appropriate toward the information and evidences that he or she get. Without siding and favoring any party, the auditor's valuation will reflect the actual condition of the client. Thus, the reliability and quality of the reports provided by the auditor could be trusted by all stakeholders.

\section{Audit Judgment}

According to Jamilah, et al (2007) audit judgment is the auditor's policy in determining the opinion of the audit result which refers to the formation of an idea, opinion or estimation about an object, event, status, or other type of events. Judgment is often required by the auditor in performing an audit of the financial statements of an entity (Zulaikha, 2006). Audit judgment attached to each stage in the audit process of financial statements, namely audit engagement acceptance, audit planning, audit testing, and audit reporting. Audit judgment is required because the audit is not conducted on all evidence. This evidence is used to express an opinion on the audited financial statements, so it can be said that the audit judgment also determines the results of the audit. Judgment is the behavior that most affected by the perception of the situation (Robin and Judge 2007).

\section{Hypothesis Development}

IAI and IAPI as an association that embraces the accounting profession in Indonesia has a professional code of ethics that is used to regulate the professionals to remain in the corridor of good ethics in carrying out the accounting profession. This professional ethics includes a standard of conduct for an auditor devoted to practical and idealistic purposes to maintain the quality of audit results and maintain the good reputation of the accounting profession. By upholding the professional ethical values of an auditor will be more objective and able to calculate appropriately in consideration of audit judgment that will be used in evaluating audit evidence obtained. Fitriani and Daljono (2012) research explains that ethical perception has a significant effect on audit judgment. Based on the above description, it can be formulated hypothesis as follows:

\section{H1: The ethical perception has positive effect on the perception of audit judgment.}

As explained by above explanation, accounting profession in Indonesia is regulated not only by law, but also by professional code of ethics that is used to regulate the accounting profession so that it could stay in the corridor of good ethics. To maintain the quality and good reputation of audit, this code of ethics must be established. Therefore, the accounting profession could hold on the code of ethics in order to maintain good reputation of the accounting profession. This 
good reputation could be achieved by encouraging professional ethical values of an auditor, so that they will tend to be more independency in carrying out their audit task. Based on the above description, it can be formulated hypothesis as follows:

\section{H2: The ethical perception has positive effect on the auditor independency.}

Independency means a mental attitude that is free from influence, not controlled by others, and not dependent on others. Independency can also be interpreted as honesty in auditors in considering facts and the existence of impartial objective consideration in deciding and expressing their opinion (Mulyadi, 2002). Independency is an important thing that the auditor must have. An independent auditor will provide a fairer and more informed judgment of the information and evidence they obtained, without any burden on any party, so the resulting judgment will reflect the actual condition of the entity being examined. Thus, the guarantee on the reliability of reports provided by the auditor can be trusted by all interested parties. This is supported by research results Singgih, et al. (2010) which explains that independency affects both simultaneously and partially to audit quality. The higher the independency of an auditor, the resulting audit quality will be better. Independency can help the auditor to consider audit judgment, so the audit quality will be better. Based on the above explanation, it can be formulated hypothesis as follows:

\section{H3: The independency has positive effect on the perception of audit judgment.}

The hypotheses development that have been developed previously emphasizes on direct effect of each relationship. In addition to that, this study is trying to test mediating effect from the role of auditor independency as the mediator of the interaction effects between ethical perception towards audit judgment taken by auditors. The logic behind this is because accounting profession will hold on to the code of ethics of accounting profession to conduct their practice in order to maintain good reputation of the accounting profession. The independency could be affected by the ethical perception of the auditors, subsequently independency held by auditors could make them do proper judgments in conducting their audit judgments.

As explained above, an independent auditor will give a more pleasant and fairer judgment of the data and prove they gotten, without any burden on any party, so the judgment they made will more reflect the real condition of the party they audited. In this way, the audit report could be ensuring on the quality of audit reports given by the auditor and can be trusted by all interested parties. Consistent with the research from Singgih, et al. (2010) which found that independency has positive effect on audit quality. The higher the independency of an auditor, the 
resulting audit quality will be better and that is because they can do more proper and appropriate judgment. Based on the above explanation, it can be formulated hypothesis as follows:

H4: The independency is able to mediate the positive relationship between the effect of ethics on the perception of audit judgment

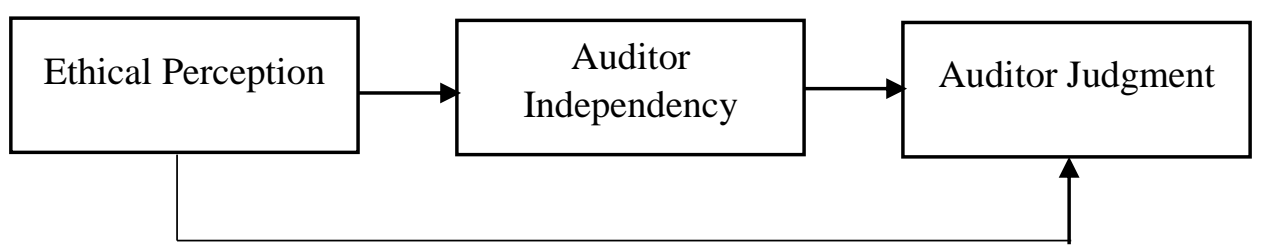

Figure 1. Research Framework

\section{METHOD}

\section{Type of Research}

The research was conducted using a survey method on Public Accounting Firms in Yogyakarta.

\section{Population and Sample}

The population of this study was all auditors throughout Public Accounting Firms in Yogyakarta with sampling done by convenience sampling method.

\section{Operational Definition and Variable Measurement}

This study consists of 2 (two) independent variables which are ethical perception and auditor independency, 1 (one) mediating variable which is auditor independency, and 1 (one) dependent variable which is audit judgment.

Professional ethic perception in this study are the values of behavior accepted and used by a particular group, in this context is the auditor or accountant profession association. Professional ethic perception variables were measured using the instruments used by Shaub and Lawrence (1996).

Auditor independency in this study is a mental attitude that is free of influence, not controlled by others, and not dependent on others. Independency was measured using the instruments used by Elfarini (2007).

Audit judgment in this study refers to a personal judgment or an auditor's perspective in response to information affecting the documentation of evidence as well as the decision making of the auditor's opinion on the financial statements of an entity. Audit Judgment variables were measured using an instrument developed by Jamilah et al. (2007). 


\section{Partial Least Square Analysis}

This research used Partial Least Square (PLS) to analyze data using SmartPLS software. PLS is structural equation modeling (SEM) based components or variance. According to Ghozali (2006), PLS is alternative approach that moves from SEM approach based covariance into variance based. Covariance-based SEM generally test causality/theory, meanwhile PLS is predictive model. PLS is a powerful analysis method because it is not based on many assumptions (Ghozali, 2006). For example, data is not always normally distributed and sample should not always be big. Besides to confirm theory, PLS can also be used to clarify the correlation among latent variables. PLS can at once analyze construct formed with reflective and formative. It cannot be performed by covariance-based SEM because it will be unidentified model.

\section{RESULTS AND DISCUSSION}

\section{Results}

\section{Convergent Validity}

In convergent validity test, indicator that has correlation value less than 0,500 should be taken out of the model because it Is considered to be unreliable and insignificant. After that, re-estimation to model will be carried out. From Figure 2, it can be shown that all indicators in the variable have correlation values more than 0,500 so that it can be used as measurement tool.

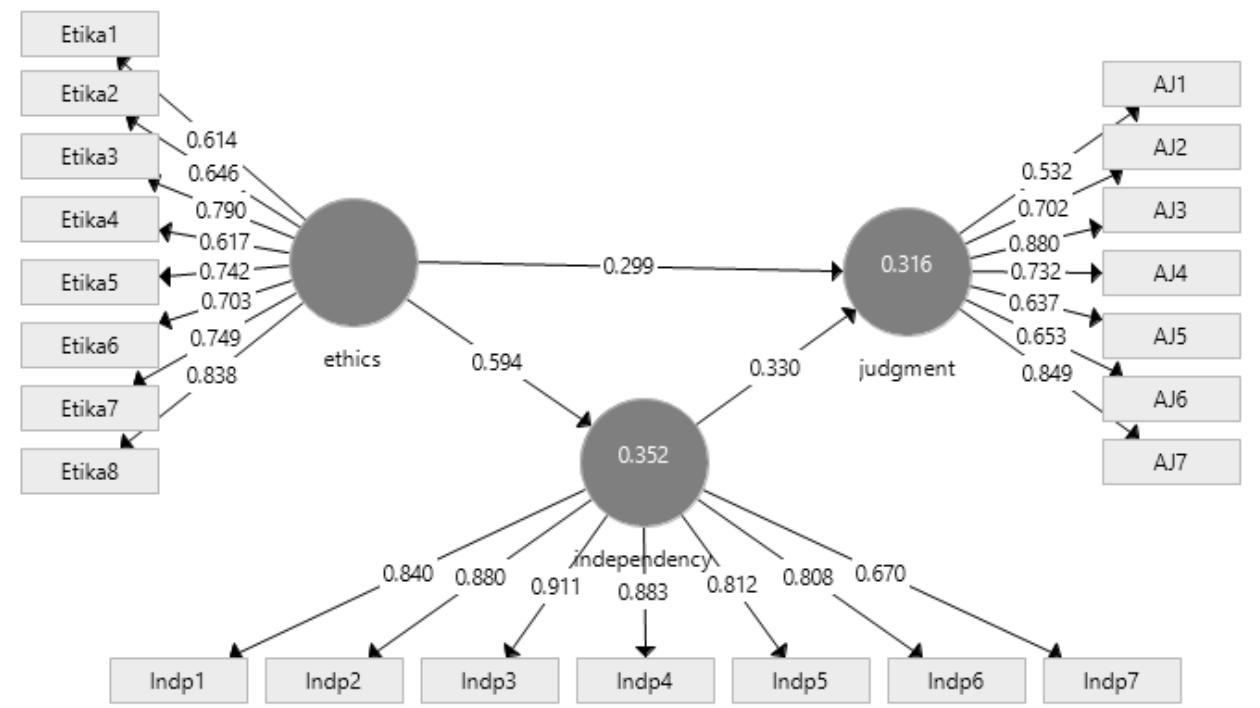

Figure 2. PLS Analysis Result and Convergent Validity Result

\section{Discriminant Validity Test}

Discriminant validity refers to the degree of nonconformity between attributes that should not be measured by the instrument and theoretical concepts 
of that variable. Discriminative validity can be said to be sufficient if AVE values are greater than 0.5. Discriminant validity test used is Fornell-Lacker Test.

Table 1. Discriminant Validity Table

\begin{tabular}{ccccc}
\hline & $\begin{array}{c}\text { Distr. } \\
\text { Just }\end{array}$ & Proc. Just & Job. Sat & Average variance extracted (AVE) \\
\hline Ethics & 0.716 & & & 0.513 \\
Independency & 0.594 & 0.832 & & 0.693 \\
Judgment & 0.495 & 0.507 & 0.721 & 0.520 \\
\hline
\end{tabular}

Based on the data in Table 1 it can be seen that the average value of variance extracted from all these variables is greater than 0.5 . Thus it can be stated that all variables have met the discriminant validity.

\section{Composite Reliability Test}

Composite reliability test is done to test reliability of research variables. Based on the data in Table 2, it can be seen that composite reliability value of ethics, independency, and judgment is higher than 0,700 . Thus, those variables are deemed as reliable.

Table 2. The result of Composite Reliability Test

\begin{tabular}{cc}
\hline & Composite Reliability \\
\hline Ethics & 0.893 \\
Independency & 0.940 \\
Judgment & 0.881 \\
\hline
\end{tabular}

\section{Structural Model Analysis}

Structural model analysis is performed by evaluating the estimation result of path coefficient parameter and its significance level. In addition, the result of significance test of path coefficient of each variable can be seen in Table 3 .

Table 3. Parameter Coefficient and Statistical Values among Variables

\begin{tabular}{lccccc}
\hline & $\begin{array}{c}\text { original sample } \\
\text { estimate }\end{array}$ & $\begin{array}{c}\text { Sample } \\
\text { mean }\end{array}$ & $\begin{array}{c}\text { Standard } \\
\text { deviation }\end{array}$ & $\begin{array}{c}\text { T- } \\
\text { Statistic }\end{array}$ & $\begin{array}{c}\text { P- } \\
\text { values }\end{array}$ \\
\hline ethics -> independency & 0.594 & 0.612 & 0.065 & 9.083 & 0.000 \\
ethics -> Judgment & 0.299 & 0.338 & 0.123 & 2.428 & 0.016 \\
Independency -> & 0.330 & 0.318 & 0.114 & 2.883 & 0.004 \\
Judgment & & & & & \\
\hline
\end{tabular}

\section{Hypothesis Testing}

The hypothesis testing is done by using $95 \%(\alpha=0,05)$ significance level.

\section{First Hypothesis Testing}

From the result of Partial Least Square analysis, it can be seen that the P- 
Value of the effect of ethical perception on audit judgments is $<0,05$. Thus, it means that partially ethical perception of auditor has significant effect on audit judgment and the first hypothesis which states that ethical perception had significant effect on auditor judgment, was supported. The result generates the value of factor loading at 0,299 which means that $29,9 \%$ of auditor judgment could be explained by ethical perception while $70,1 \%$ was determined by other factors.

\section{Second Hypothesis Testing}

From the result of Partial Least Square analysis, it can be seen that the PValue of the effect of ethical perception on auditor independency is $<0,05$. Thus, it means that partially ethical perception has significant effect on auditor independency and the second hypothesis which states that ethical perception had significant effect on auditor independency, was supported. The result generates the value of factor loading at 0,594 which means that $59,4 \%$ of auditor independency could be explained by ethical perception while 40,6\% was determined by other factors.

\section{Third Hypothesis Testing}

From the result of Partial Least Square analysis, it can be seen that the PValue of the effect of auditor independency on auditor judgment is $<0,05$. Thus, it means that partially auditor independency has significant effect on auditor judgment and the third hypothesis which states that auditor independency had significant effect on auditor judgment, was supported. The result generates the value of factor loading at 0,330 which means that $33,0 \%$ of auditor judgment could be explained by auditor independency while $77,0 \%$ was determined by other factors.

\section{Mediating Effect Testing}

In statistics, the Sobel test is a method of testing the significance of a mediation effect. In mediation, the relationship between the independent variable and the dependent variable is hypothesized to be an indirect effect that exists due to the influence of a third variable (the mediator). As a result, when the mediator is included in a regression analysis model with the independent variable, the effect of the independent variable is reduced and the effect of the mediator remains significant. The Sobel test is basically a specialized t test that provides a method to determine whether the reduction in the effect of the independent variable, after including the mediator in the model, is a significant reduction and therefore whether the mediation effect is statistically significant. From the result of Sobel test table showed in table 4, it can be concluded that auditor independency could 
mediate the positive relationship between ethics and auditor judgment. Therefore, the hypothesis 4 is supported.

Table 4. Result of Sobel Test

\begin{tabular}{lr}
\hline Model: Ethics $\rightarrow$ Independency $\rightarrow$ Audit Judgment & \\
\hline $\mathrm{A}$ & 0.594 \\
$\mathrm{~B}$ & 0.330 \\
$\mathrm{SE}_{\mathrm{A}}$ & 0.065 \\
$\mathrm{SE}_{\mathrm{B}}$ & 0.114 \\
Sobel Test Statistic & 2.75959744 \\
One-tailed prob. & $0.00289363^{*}$ \\
Two-tailed prob. & $0.00578726^{*}$ \\
\hline
\end{tabular}

\section{Discussion}

Based on the results obtained, it is known that ethical perception variable has significant effect on audit judgment perception. This implies that the higher the professional ethics the audit judgment perception is higher too. The results of this study are in accordance with previous research from Art Fitriani, Daljono (2012) which explains that ethical perception have a significant effect on audit judgment. Therefore, hypothesis 1 (H1) is accepted.

Statistical test results of ethics variables concluded that ethical perception have significant effect on auditor independency. This implies that the higher the ethics the auditor independency is higher too. The results of this study supported hypothesis 2 (H2).

Variable Independency testing concluded that independency has a positive influence on audit judgment perception. This implies that the higher the independency, the perception of audit judgment obtained is also higher. This result is in accordance with the research Singgih, et al (2010) which explains that independency affects both simultaneously and partially to audit quality. Independency can help the auditor to consider audit judgment, so the audit quality will be better. Therefore, hypothesis 3 (H3) is accepted.

The hypotheses testing that have been discussed before mainly discuss about the direct effect of each relationship. In addition to that, the result of this study also found that there is significant role of auditor independency as the mediator of the interaction effects between ethical perception towards audit judgment taken by auditors. So, it proves that because accounting profession is hold on to the code of ethics of accounting profession to conduct their practice in order to maintain good reputation of the accounting profession. Then, independency could be affected by the ethical perception of the auditors, subsequently independency held by auditors could make them do proper judgments in conducting their audit judgments. This means that the independency 
could be the mediator between ethics and audit judgment. This result supported hypothesis 4 (H4).

\section{CONCLUSION AND IMPLICATION}

This study aims to determine the positive effect of ethics and independency on the audit judgment and also the mediating effect of independency on the positive relationship between ethics and audit judgments. Based on the results of data analysis and discussion that has been explained above, there are some things that can be concluded from this research, ethics has significant positive effect on audit judgment. This means that the more ethics the auditors have, the better judgments they will make. Independency has significant effect on audit judgment. This shows that auditors who have strong independency will be able to take a relatively better and qualified audit judgment. It is also found that independency could mediate the relationship between ethics and auditor judgments. It means that when the auditors ethics is good, they will also have good independency and hence they will do better judgments.

From the results of this study, it can be implied that auditor ethics and independency is very important for auditor in order to make better judgment. Therefore, both public accounting firms and Institute of Indonesia Chartered Accountants (IAI) should concern on the ethical and independency issues of auditor, so that the result of auditor's works, such as audit opinion, etc. could be proper and accurate so that the user of the financial and annual report could use the reliable report.

\section{REFERENCES}

Arens, Alvin. A., dan James K. Loebbecke. 2003. Auditing, Pendekatan Terpadu, Terjemahan Amir Abadi Jusuf, Salemba Empat, Jakarta.

Boynton, William C., dan Jhonson Raymond, Walter G. Kell. 2003. Modern Auditing Edisi Ketujuh. Erlangga. Jakarta.

Elfarini, Eunike Christina. 2007. "Pengaruh Kompetensi dan Independensi Auditor Terhadap Kualitas Audit. Jurnal Dinamika Akuntansi.

Fitriani, Seni and Daljono. 2012. Pengaruh Tekanan Ketaatan, Kompleksitas Tugas, Pengetahuan Dan Persepsi Etis Terhadap Audit Judgement. Diponegoro Journal of Accounting, 1(1): 1-12

Ghozali, Imam. 2006. Struktural Equation Modeling Metode Alternatif dengan Partial Least Square (PLS). Semarang: Badan Penerbit Undip Semarang. 
Hartanto, Hansiadi Yuli and Indra Wijaya Kusuma. 2001. "Analisis Pengaruh Tekanan Ketaatan Terhadap Judgment Auditor”. Jurnal Akuntansi dan Manajemen, Ed. Desember: 1-14.

Ikatan Akuntan Indonesia. 2001. Standar Profesional Akuntan Publik Per 1 Januari 2001. Salemba Empat. Jakarta

Jamilah, Siti, Zaenal Fanani, and Grahita Chandrarin. 2007. Pengaruh Gender,Tekanan Ketaatan, dan Kompleksitas Tugas terhadap Audit Judgment. Simposium Nasional Akuntansi 10, Makassar

Mulyadi. (2002). Auditing 1 : Edisi Enam. Salemba Empat. Jakarta

Robin,S.P., and Judge, T.A. 2007. Organizational Behavior, Pearson Educations, 12th ed

Shaub, Michael K., and J. Lawrence. 1996. Ethics, Experience and Profesional Skepticism : A Situasional Analysis. Behavioral Research in Accounting 8: $124-157$

Singgih, Elisha Muliani and Icuk Rangga Bawono. 2010. Pengaruh Independensi, Pengalaman, Due Professional Care dan Akuntabilitas Terhadap Kualitas Audit. Simposium Nasional Akuntansi 13, Purwokerto

Zulaikha, 2006. Pengaruh Interaksi Gender, Kompleksitas Tugas, dan Pengalaman Auditor terhadap Audit Judgment. Simposium Nasional Akuntansi 9, Padang 